The Geneva Papers on Risk and Insurance, 21 (No. 80, July 1996), 401-420

\title{
Large-scale Technological Risks A Challenge for Insurers and Reinsurers
}

\author{
by Heinz Huppmann and Georg Duesing*
}

\section{Introduction}

Intensive coverage of current issues in the media and also modern techniques of trace analysis have helped to make us all aware of the natural and man-made threats to our habitat, the earth. The principal threats include overpopulation, the dwindling of our natural resources, climate change, pollution and radioactive contamination. This new awareness has led to a widespread, subjective and often emotionally exaggerated fear of technology and its consequences. Technological developments, including those that are designed to combat existing threats, are viewed sceptically and are even being rejected completely. The philosopher Mittelstraß warns us: «Mankind's problems do not stand still even if mankind itself does not move forward. Remaining at the current stage of scientific and technological development does not reduce the risk of the Leonardo world, but rather increases it.»[1] This statement is all the more true if one regards emerging socio-political conflicts like civil wars and large-scale migration not only as consequences of ideologies and nationalism but also as long-term consequences of unsolved threats such as overpopulation and a lack of resources.

Unhurried development of technologies, exercising due care for mankind and the environment and displaying more risk-awareness with a view to a more perfect and, if possible, more forgiving use of natural laws certainly offers mankind a better chance of enjoying a risk-free life than does a complete rejection of technological progress. It is therefore appropriate to consider foreseeable future technological developments and their possible effects on man and the environment now rather than later.

*Heinz Huppmann, professional engineer, is Head of the Engineering Insurance Department and a Member of the Executive Management, Munich Re, Munich. Dr. Georg Duesing, physicist, is a Deputy Member of the Executive Management, Munich Re, Munich. 
This risk potential presents the insurance industry with a great challenge in a rapidly changing environment characterised by enormous upheaval.

\section{Changes affecting the operations of insurers and reinsurers}

\subsection{Trends affecting industrial insureds}

The public sector is increasingly transferring its responsibility and financing of longterm infrastructure projects, such as transportation, utilities, waste disposal, energy and communications technologies, to private investors. The lack of efficiency the public sector has displayed in servicing many economic sectors has induced central governments, regional governments and local authorities to privatise these state-run and municipal economic sectors and restrict their activities to awarding contracts and supervision. In doing this, the public sector has also transferred the financial risks to private investors, who naturally want to minimise their operating risk. This trend towards the state taking a back seat has therefore created new demand for the provision of extensive insurance cover.

In many parts of the world, private investors and financial services companies form consortiums which invest in both traditional and innovative projects. In order to cover their long-term financing models in the construction and operating phases, they require reliable, long-term insurance protection which covers the costs of property damage, purely financial losses and liability claims.

This private financing frequently involves so-called BOT (build, operate, transfer) models. An international production and financing consortium receives from the state the licence to finance, construct and operate (albeit for a limited period only) a major technical installation, such as a power station, a motorway, a tunnel or, to cite a topical example, the new airport of Athens.[2] This erection and operation consortium agrees to hand the installation over to a local operator after a stipulated period, for a fixed residual value or for the current operating value. This results in a long-term risk for the consortium. In addition to Contractors' All Risks (CAR) and Erection All Risks (EAR) insurance, it is becoming increasingly common for the consortiums, frequently at the instigation of the banks financing the project, to take out very risk-specific insurance cover to minimise purely financial losses resulting from delays in operation caused by indemnifiable property damage. These types of cover are known as «Advance Loss of Profits (ALOP)», «Delay in Completion» or «Delay in Start-up». In the operating phase of a project, these types of insurance are replaced by the classic property insurances such as Fire insurance with Fire Business Interruption, Machinery insurance with Machinery Loss of Profits, Public Liability insurance and Environmental Liability insurance.

These very long-term insurance agreements, extending over 10 to 25 years, require careful risk assessment, expert control via inspections during the policy period and highly specialised risk-related know-how for claims handling and for determining the insurer's and reinsurer's prices and conditions. The capacity requirements for these covers can approach the current limits of the world's insurance markets for projects such as major power stations, semiconductor factories, and extensive infrastructure works, such as major airports on reclaimed land or tunnels for rapid rail and road links. 


\subsection{Trends affecting insurers}

These developments on the insureds' side mirror developments taking place in the insurance industry, which is characterised by worldwide deregulation and an increased globalisation of large insurance groups. Through takeovers and mergers, nationally operating insurance groups are becoming "global players", whose reinsurance requirements are concentrated on major industrial risks and extensive accumulation risks in certain critical regions of the world, which are not necessarily only caused by natural hazards. These globally operating insurers support their regional subsidiaries in a frequently fierce, turnoveroriented competitive fight against local companies and engage in an international struggle for market shares, even accepting losses for a limited period of time.

\subsection{Consequences for the reinsurer}

The international and indepedent professional reinsurer wants to work together with both "global players" and locally operating insurers. Traditionally, the reinsurer promotes the development of strong and healthy local insurance markets. The only way to do this successfully is via a transfer of know-how to the local markets and through a profit-oriented approach on the part of insurers and reinsurers.

Especially in countries with high investment and growth potential, these developments result in insurers placing increased demands on reinsurers in terms of their capacity, know-how and their willingness to accept risks. Consequently, smaller reinsurance companies and larger Lloyd's syndicates have withdrawn more rapidly and larger reinsurance groups have been formed as a result of takeovers by competitors. The underlying objective is the necessity to be suitably equipped for the higher requirements of the future with regard to the above-mentioned demands as well as market experience and financial soundness.[3]

In the area of the greatest reinsurance requirements, i.e. large-scale risks and accumulation risks, a good opportunity exists for fruitful and mutually beneficial cooperation between insurers in the local markets, international insurance groups and globally operating professional reinsurers. In many countries, this extensive cooperation is still supported by state protection of the national insurance industry, not least due to ist importance as a capital market for co-financing investments. All parties involved are gradually realising that cooperation based on trust will be the only way to succeed in these markets.

The reinsurer that has been operating in such markets for decades has, often at considerable expense, not only obtained specialised local knowledge, which the emerging newcomer does not have, but also has decades of close professional and personal relations with those people who have to prove themselves in the competition that now prevails between the local insurers and their international competitors with regard to premiums, conditions, competent handling of risks and correct claims management. As the reinsurer usually has longstanding business relations with both competing groups of insurers, he will certainly have to prove his ability to reconcile interests and to maintain harmonious cooperation. This will only be recognised by his clients if satisfactory results are achieved for all parties concerned.

There can only be one way of achieving this difficult multilateral cooperation. The reinsurer must be prepared to offer his clients the chance to benefit from the store of 
information he has acquired through many years of global, profit-oriented operations. This requires intelligent, retrospective evaluation of his extensive databases of written risks and incurred losses coupled with exposure-oriented, prospective design of prices and conditions, if possible on a regional basis. All of this must be up-to-date and readily available via modern tools, i.e. PC-based and with an online network between headquarters and the regional offices in the local markets. Thus the reinsurer will be able to maintain optimal cooperation with internationally operating insurers and his local partners, with a view to considering their specific capacities in the distribution of major risks with which individual markets and insurers have not yet been able to gather sufficient experience. At this present time, this is on the one hand of particular relevance to innovative large-scale technical risks involving energy, transport and semiconductor manufacturing technologies. On the other, the evaluation of accumulation hazards in the critical regions of the world will in the foreseeable future remain a domain reserved for the internationally operating reinsurer, in view of his experience and scientific work on a broad basis. These two pillars of the reinsurer's operations and know-how are the very two areas of service that national and international insurers expect and are also the areas that especially require capacity support from the reinsurer.

By means of examples this paper will look at various areas of technology which present particular challenges to the insurance industry today, and even more so in the future, above all with regard to reinsurers' financial capabilities.

\section{Energy technology}

\begin{tabular}{|c|c|c|}
\hline & conventional & renewable \\
\hline 2050 & - Nuclear fusion & $\begin{array}{l}\text { - Solar energy via satellite } \\
\text { - Tidal power, wave energy and solar } \\
\text { chimney power }\end{array}$ \\
\hline 2010 & $\begin{array}{l}\text { - Superconduetors in generators, } \\
\text { transformers, transmission lines } \\
\text { - Low-loss energy transmission }\end{array}$ & $\begin{array}{l}\text { - Fuel cells } \\
\text { - Hydrogen as energy carrier } \\
\text { - Large photovoltaic plants in } \\
\text { sunny regions }\end{array}$ \\
\hline 2000 & $\begin{array}{l}\text { - Nuclear power stations } \\
\text { with inherent and active high } \\
\text { safety features } \\
\text { - Fast breeder reactors } \\
\text { - High-temperature nuclear } \\
\text { power stations in modular } \\
\text { construction form }\end{array}$ & $\begin{array}{l}\text { - Photovoltaic solar energy } \\
\text { - Thermal solar energy } \\
\text { - Geothermal energy } \\
\text { - Wind energy } \\
\text { - Hydroelectric power }\end{array}$ \\
\hline 1995 & $\begin{array}{l}\text { - Gas and steam combined cycle } \\
\text { stations } \\
\text { - Bolling-water/pressurised-water } \\
\text { nuclear power stations } \\
\text { - High-voltage direct-current trans- } \\
\text { mission }\end{array}$ & $\begin{array}{l}\text { - Energy saving technologies, } \\
\text { heat pumps, thermal insulations }\end{array}$ \\
\hline
\end{tabular}

Synopsis of energy generation 


\subsection{Primary energy demand}

Energy technology[4] will have to solve the core problem of our earth and its growing population, which will reach 8 billion people by the year 2020. The estimation of future primary energy demand is determined by assumptions of economic growth. In a study by the World Energy Council[5] several scenarios are investigated. Between a growth scenario and an environmental-protection scenario lies the basis scenario, which assumes global economic growth as in the second half of the 1980s and is rather optimistic with regard to the reduction in energy intensity, i.e. the increase in the efficiency of using energy.

The modified basis scenario assumes a later and slower reduction in energy intensity.

The basis scenario concludes that today's annual world energy consumption of 12.6 billion tonnes of coal equivalent (tce) will have increased to 19.1 billion tce by the year 2020. The modified basis scenario puts this figure at 22.9 billion tce.

Figure 1 shows how energy consumption is distributed among the different regions of the world and how the different primary energy sources account for the supply of these requirements.

Figure 1 Development of world primary energy consumption by region and energy carrier, 1990 and scenarios for 2020.[5] (tce = tonnes of coal equivalent).
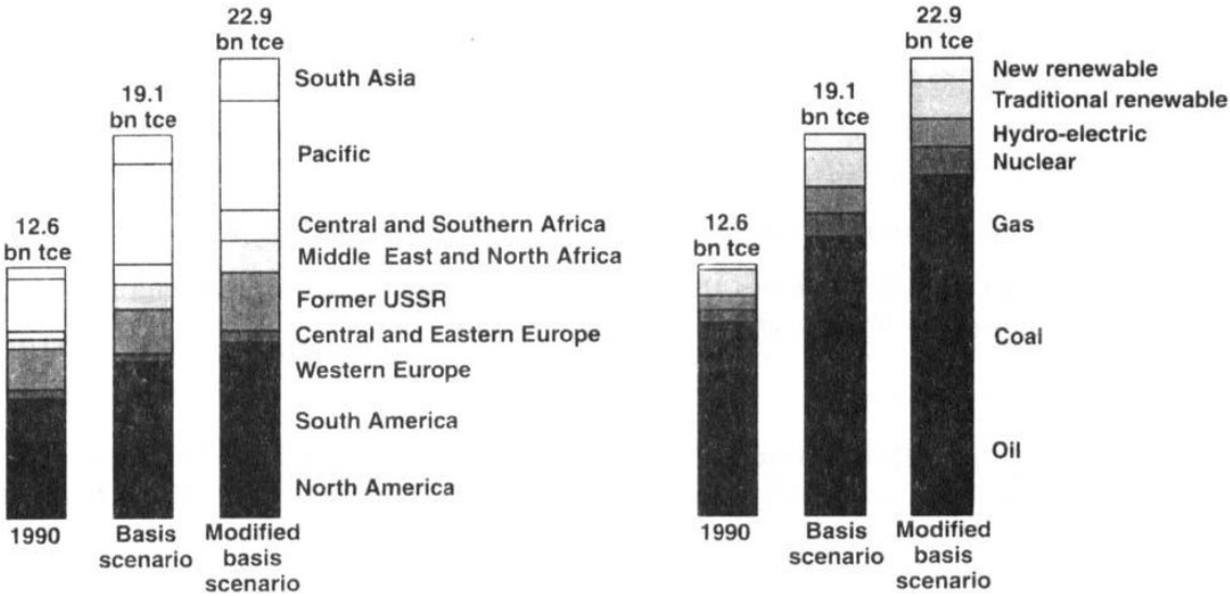

In Figure 2 an attempt is made to extend predictions up to the end of the next century. Although energy consumption in the northern hemisphere will fall dramatically thanks to more efficient use of energy, the corresponding growth in the southern hemisphere will be far greater, due to the backlog demand in per-capita consumption and above all due to the ever-increasing population in these parts of the world. 
Figure 2

Long-term prognosis on the development of population, per-capita primary energy consumption and total primary energy consumption.[6] (toe = tonnes of oil equivalent).
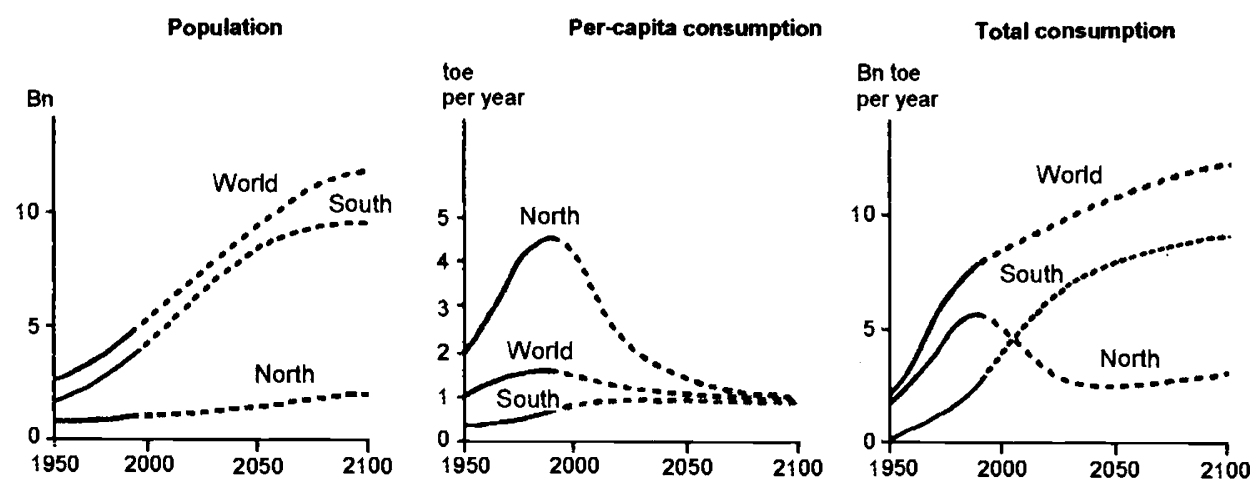

\subsection{Offshore technology}

An example of major technological risks in the area of primary energy is the production of oil and gas from deposits under the sea bed. The employed technology has been in a state of radical change for some years. The trends are determined by three major factors:

- Deep-water reserves are becoming more important in economic terms.

- Marginal fields, i.e. those with small amounts of oil and gas, are being increasingly exploited, especially if existing infrastructure is close by.

- Cost efficiency is of paramount importance due to low oil and gas prices.

The following section describes the most important new types of installation, which have emerged as a result of these changing requirements.

\subsubsection{Rigid support structures}

The days of rigid support structures, hundreds of metres high and fixed by piles to the sea bed, are over. The record height for such a structure was Bullwinkle in the Gulf of Mexico at $490 \mathrm{~m}$, as high as the tallest buildings on land. Platform support structures of this kind are no longer built on account of the excessively high costs.

The same is true of the enormous concrete towers, which stand on the sea bed without the assistance of piles by virtue of their own weight and the weight of the heavy containers they are connected to. The Troll gas platform will remain the only platform of this type reaching a height of $370 \mathrm{~m}$. It was built in a Norwegian fjord. This structure, consisting of $660,000 \mathrm{t}$ of steel-reinforced concrete with its over 30,000 t topside, was towed into position at a water depth of $300 \mathrm{~m}$ above the Troll gas field in the North Sea in 1995. Simultaneously, the pipelines from the platform to the terminal on the Norwegian main- 
land were laid. The entire project cost DM 7.5 billion, $40 \%$ for the platform, $40 \%$ for the terminal and $20 \%$ for the pipelines.

A particular problem involving these structures with their hundreds of thousands of tonnes of concrete are the costs for their eventual disposal. Such heavyweight platforms, which make up only $6 \%$ of all platforms in the North Sea, will account for roughly two thirds of all disposal costs. The costs for disposing of all current North Sea platforms is estimated at DM 26 billion, approximately equivalent to Norway's annual tax revenue.

\subsubsection{Tension leg platforms}

Tension leg platforms (TLP) are a much more cost-effective solution for deep-sea production. The platform topsides are carried by a so-called semisubmersible, a floating unit the buoyancy volumes of which are located some $25 \mathrm{~m}$ below the water surface. This semisubmersible is anchored to the sea bed by tensioned tethers and then pulled several metres deeper into the water. This technique allows the platform to stand in the water almost completely unaffected by waves and wind, which is a great advantage for drilling and production compared to free-floating units.

In 1994, the Auger TLP went into production. This platform is situated in the Gulf of Mexico at a water depth of $870 \mathrm{~m}$, which is a clear record for such structures. There were phases during the installation of Auger which not only gave the project team a fright but also gave insurers great cause for concern.

The hull, a semisubmersible with an area of $100 \mathrm{~m} \times 100 \mathrm{~m}$ and a height of $60 \mathrm{~m}$, was towed across the Atlantic from Italy under its own buoyancy and ran into a bad storm at the beginning of ist 110-day trip of over 6,800 sea miles.

The situation became more serious when the deck and its superstructures were delivered late and the two most difficult phases of installation had to be delayed. The floating of the deck on to the hull had to be carried out at the height of the hurricane season and the remote-controlled anchoring of the TLP to the sea bed in the worst of the Gulf of Mexico winter. Both these factors constituted a significant risk aggravation, which no experienced insurer would have accepted if it had been proposed in the original project schedule. The positioning of the $24,000 \mathrm{t}$ deck supported by barges over the free-floating $20,000 \mathrm{t}$ hull and their interconnection on open sea during the hurricane season was a unique and high-risk operation.

In addition, the product pipelines had to be laid at this record depth and brought up to the platform. Even experts considered these operations to be virtually impossible under such conditions, but the project was completed successfully.

The latest installation of this type is Heidrun, the northernmost platform in the North Sea. This DM 3.5 billion project was given the go-ahead in 1991 and the first oil produced in 1995 . With a water displacement of $290,000 \mathrm{t}$, this floating unit is a veritable colossus. For the first time the hull was made of concrete. The superstructures weigh $65,000 \mathrm{t}$.

\subsubsection{Subsea technology}

It is uneconomical to erect fixed platforms over fields with only small oil or gas reserves. The method that has been adopted here is to drill wells by means of a floating 
drilling unit and to complete them on the sea bed. From there the product is transported through pipelines to a central platform, which can be either fixed or floating. Efficient combinations result when newly opened marginal fields are situated in the vicinity of existing fields, whose platforms have excess processing capacity available.

The well completion on the sea bed includes a blowout preventer and a distribution structure for transporting the product and for supplying the well with chemicals and measuring equipment as well as installations for subsequent maintenance operations.

Although these subsea stations are relatively inexpensive, repairs can be extremely costly. In 1992 for example, during the commissioning of a major subsea system in the North Sea, a simple electrical fault in a distribution module occurred, which on a platform could have been repaired in a few days. Here it required the deployment of four remotecontrolled underwater vehicles and delayed the start of production by 2.5 months.

\subsubsection{Directional drilling}

Even smaller fields can be exploited profitably if they can be reached directly by drills from existing platforms. This is where the techniques of directional drilling come into play. This technology makes it possible to change direction during the course of a drilling operation and even carry out horizontal drilling deep in the sea bed.

A good example of this is the Gulfaks West field in the North Sea, which went into production in 1994. Here a single well was able to reach five small oil deposits at a depth of $2,000 \mathrm{~m}$ under the sea bed by means of horizontal drilling which changed direction by an angle of up to $180^{\circ}$ over a distance of several thousand metres.

\subsubsection{Troll oil project}

One project that combines several of these new technologies is the Troll oil field, which began production in 1995 . In this project the $35,000 \mathrm{t}$ superstructures of the central unit are carried by a free-floating semisubmersible made of $140,000 \mathrm{t}$ of concrete and anchored with $8,000 \mathrm{t}$ chains at a water depth of $330 \mathrm{~m}$.

The field has 23 wells, which are all completed on the sea bed. The product is transported in pipelines to 5 collecting stations on the sea bed and and conveyed to the platform from there. The oil reservoir is very shallow and has a height of only $25 \mathrm{~m}$. It is therefore exploited by wells which extend horizontally between $500 \mathrm{~m}$ and 2,000 m.

The Troll oil installation forms a remarkable contrast to the nearby concrete towers of the Troll gas platform mentioned at the beginning of this section, with its equally fascinating but now obsolete technology.

\subsection{Electricity demand}

Future demand for electricity and thus the number and type of power stations to be built are of particular interest to the reinsurer. Consumption of electricity will continue to increase faster than primary energy consumption as a whole. According to the basis scenario mentioned earlier, electricity consumption will double in the period between 1990 and 2020 from an annual demand of $11,600 \mathrm{TWh}$ to $23,000 \mathrm{TWh}$. 
Growth rates will vary greatly from region to region. With the very high current percapita consumption in North America, western Europe and the CIS, annual growth will be between $1.0 \%$ and $1.5 \%$; with the very low current per-capita consumption in South Asia, Central and South America the growth rates will be between $3.9 \%$ and $4.7 \%$.

These figures are important for the reinsurer in order to estimate the future demand for power stations and the resulting need for insurance. If one proceeds from the assumption that the additional electricity demand will only be covered by large power stations with an output of $700 \mathrm{MW}$, this would result in a need for 2,000 additional power stations worldwide for the period under consideration. Additionally, a further 2,000 power stations of similar dimension would be needed to replace disused plants.

Altogether, this results in an average annual requirement of approximately 130 new such power stations. This requirement will be covered by different types of power station and different plant sizes. For the period under consideration, the most important types of plant will be coal-fired power stations, natural-gas-fired combined-cycle power stations with gas and steam turbines, single-cycle gas turbine power stations, hydro-electric power stations and nuclear power stations. In the conventional power station sector, gas-fired combined-cycle stations will increasingly replace classic steam power stations in many parts of the world.

This is quantified in Figure 3 for the next 10 years. The potential for the construction of power stations applies to additional requirements and replacement requirements together. Using current prices for the different types of power station as a basis, the data

\section{Figure 3}

World electricity production, prognosis 1994 - 2003 for the construction of new and replacement power stations (total potential $820,000 \mathrm{MW}$ ).[7]
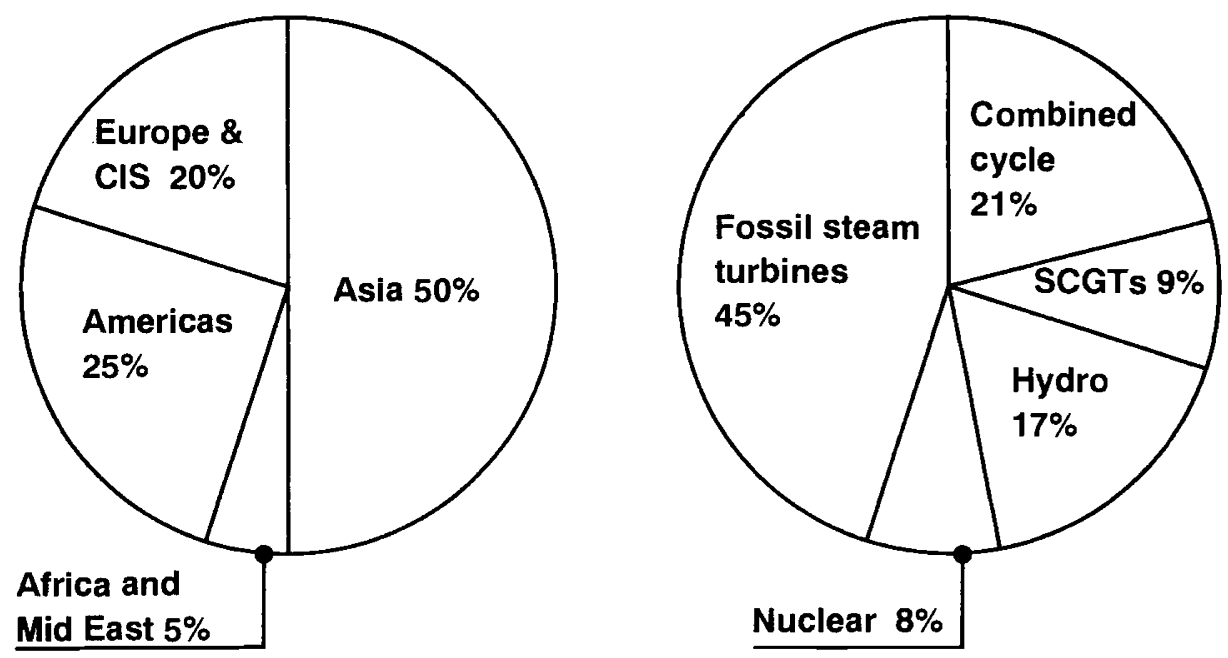
results in an average annual investment volume of DM 180 billion worldwide for the period stated. Using the data in Figure 4, the investment volume for Asia alone amounts to DM 95 billion. Asia is without doubt the most important growth market of the future in the energy sector. Figure 4 also shows the regional distribution within Asia. Electricity demand in China will be subject to the strongest growth.

Figure 4

Electricity production in Asia, prognosis 1994 - 2003 for the construction of new and replacement power stations (total potential 410,000 MW).[7]
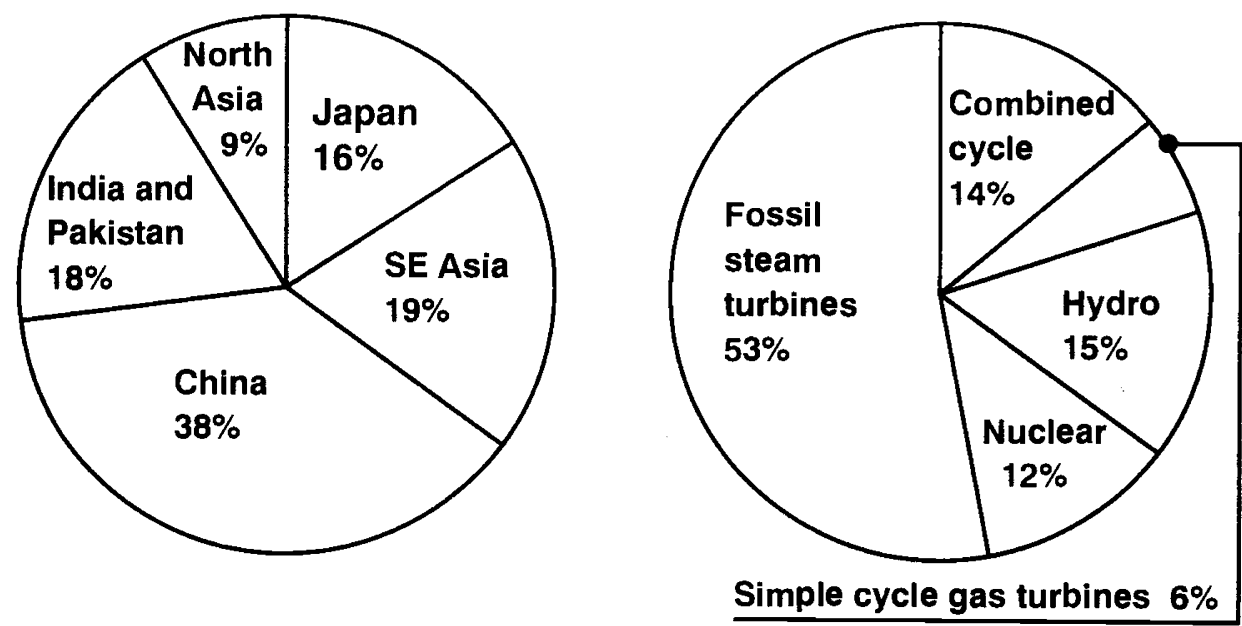

As a comparison of the two charts shows, $3 / 4$ of the nuclear power stations to be built in the next 10 years will be located in Asia, namely some 50 major installations. A number of developing countries in Asia are opting for nuclear energy, with some countries planning to supply up to $50 \%$ of their electricity needs from this source.

\subsection{Fuel reserves}

In view of the expected strong increase in the demand for primary energy and in the consumption of the particularly valuable secondary energy source, electricity, it is important to know the situation regarding energy reserves.

More than $80 \%$ of the world's total commercial energy needs will still be covered by fossil fuels in 30 years' time, with transportation becoming an ever-increasing consumer. Today's proven and economically viable reserves of fossil fuels amount to 780 billion tce of coal, 200 billion tce of oil and 190 billion tce of natural gas.[8]

If one assumes purely hypothetically that current annual consumption remains at its present level and that no new deposits are discovered, coal reserves will last 235 years, 
natural gas 65 years and crude oil 42 years.[8] Such calculations obviously do not mean that the reserves will be exhausted after these time spans. For example, the proven reserves of natural gas have doubled in the last twenty years in spite of the strong increase in annual consumption.

Nuclear energy accounts for $18 \%$ of global electricity production. The current reserve lifespan of uranium, the most important nuclear fuel, is 57 years, if one considers only those reserves which can be mined from natural deposits for less than $\$ 130$ per kg.[9] However, a scarcity of uranium is not to be anticipated because, in addition to the great stocks of mined uranium, there are also supplies of plutonium, which is obtained from reactors, and nuclear fuel from the scrapping of nuclear weapons. Consequently, there is no immediate need to build fast breeder reactors to produce nuclear fuel.

It is therefore safe to assume that in the period under consideration the fuels to operate power stations will be available in sufficient amounts and at acceptable prices. This is a condition that has to be met if private investors are to take on long-term commitments in the power generation sector.

\subsection{Fossil-fuelled power stations}

\subsubsection{Coal-fired power stations}

$45 \%$ of the world's electricity is currently produced in coal-fired power stations.[9] Although the burning of coal with ist resultant release of $\mathrm{CO}_{2}$ and the often uncontrolled release of $\mathrm{SO}_{2}$ and $\mathrm{NO}_{\mathrm{x}}$ would make a reduction in such power stations desirable, this is not to be expected in the next few decades, as developing countries and threshold countries will cover a high proportion of their growing electricity needs from supplies of domestic coal.

In spite of the technological improvements made over the decades, coal-fired power stations still involve considerable risks. This is not only true of new technologies employed, such as flue gas desulphurisation plants, but also of the conventional parts of power stations. The following loss is a good example.

In the $150 \mathrm{MW}$ block of the coal-fired power station at Lünen a boiler explosion occurred in October 1994 during a test run following the annual maintenance. It is assumed that after a pipe burst, a large amount of water streamed on to the more than $1500^{\circ} \mathrm{C}$ hot molten ash, which resulted in a steam explosion and possibly in the formation of hydrogen and thus a hydrogen explosion. The boiler was completely destroyed. A great deal of damage was also caused by flying debris. Fortunately, nobody was injured. This loss was settled at DM 100 million.

\subsubsection{Combined-cycle power stations}

Combined-cycle power stations, which combine gas and steam turbines, have, along with single-cycle gas turbine power stations, enjoyed great success since the late 1980s. It is to be expected that $40 \%$ of the capacity from the fossil-fuelled power stations to be built over the next ten years will come from these two types.[7] Combined-cycle power stations have several important advantages, and there is no doubt that they will continue to be suc- 
cessful, especially in view of the stabilisation in the natural gas market and its competitive prices.

- Thanks to the combination of gas- and steam-turbine cycles, these power stations are approximately $35 \%$ more efficient than conventional steam power stations. This high level of efficiency means a high exploitation of fuel and thus a reduction in the levels of carbon dioxide released and a lower risk for the climate, and all this with a fuel that when burned in a boiler releases only half the carbon dioxide released by coal for the same amount of generated heat.

- Combined-cycle power stations have short construction and financing periods.

- The investment costs are a third lower.

-. The modular form of construction allows units to be extended without difficulty.

These last three points in particular make such power stations especially attractive for threshold countries.

The key to this success was and still is the development of gas turbine technology. In the early 1970 s gas turbines had outputs of $50 \mathrm{MW}$. Today they achieve values of up to 240 MW and efficiency levels of $38 \%$, which means that combined-cycle power stations have an overall efficiency of $58 \%$. The main reasons for the improvements in gas turbines are the increased gas inlet temperature and the optimisation of the blade design.

In order to achieve this rapid development, the properties of the materials used and the constructional tolerance levels were stretched to the limit. It is thus not surprising that the numerous new types of turbine which were brought on to the market within a short time by only four competing companies (GE, Westinghouse, ABB and Siemens, and their licensees) were not as completely tested as operators and insurers would have wished. Consequently, there were a great number of losses involving gas turbines. Particularly catastrophic was a major loss in a combined-cycle power station in Leipzig in November 1994 following the rupture of the largest gear wheel, which resulted in 5 people being killed and 23 seriously injured.

\subsection{Hydro-electric power stations}

The future will bring intensive use of the oldest renewable solar-driven energy system, hydro-electric power, as a result of more efficient transmission from producers to consumers. Hydro-electric power still has an unused potential of $85 \%$ of the globally available 2-3 TW and could then supply $10 \%$ of the world's energy needs as opposed to the $2.6 \%$ that it provides today. In Germany, there is hardly any potential for additional hydro-electric power stations. However, they are the ideal source of electricity for many threshold countries - in spite of the high investment costs. Moreover, they are also the only important renewable source of energy in the near future.

New dimensions of turbine design are also being reached with hydro-electric power stations. For Pelton turbines the record output is $260 \mathrm{MW}$ per unit. Two turbines of this type are used at the Sellrain-Siltz power station, where the water head is $1,230 \mathrm{~m} .400 \mathrm{MW}$ turbines are under construction and are due to go into operation at the Swiss power station Grande Dixence when it is expanded in 1998 . The water from the storage lake Lac des 
Dixes will shoot down into the Rhône valley $1,860 \mathrm{~m}$ below and on to the new turbines at a speed of $690 \mathrm{~km} / \mathrm{h}$. From the very beginning Grande Dixence has set new standards. The dam wall, completed in 1961, is still the highest in the world. Thanks to its large storage volume, this power station plays a major part in the supply of electricity to western Switzerland, where hydro-electric storage plants, whose output is easy to regulate, cover peak demand, while nuclear power stations take care of the constant basic demand.

\subsubsection{China}

In 1992 the Chinese government gave the go-ahead for the construction of additional hydro-electric power stations, with the firm intention of changing the structure of the power generating industry in China and to limit the importance of coal-fired power stations, not so much due to the pollution they cause but rather in order to reduce the need to mine and transport coal. Currently, coal shipments account for $40 \%$ of China's rail freight. Large and medium-sized hydro-electric power stations with a combined output of over $20,000 \mathrm{MW}$ are under construction, with plants of $100,000 \mathrm{MW}$ output on the drawing board.

Most impressive is the gigantic Three-Gorges Project in the steepest parts of the Yangtze, the construction of which was authorised by the Chinese Congress in 1992. It will be the largest hydro-electric power station in the world with nearly $18,000 \mathrm{MW}$ from 26 turbo generator units and high-voltage DC transmission extending as far as Shanghai over a distance of more than $1,500 \mathrm{~km}$. The dam will have a height of $175 \mathrm{~m}$. The project also includes a shipping sluice with 5 levels. The storage lake will cover an area currently inhabited by more than 700,000 people, thus necessitating a massive resettlement programme. One ecological advantage in connection with the power station is flood control. This project will reduce the return period for a major flood downriver from 10 years to 100 years. Production of electricity will begin after a construction period of 9 years, after which the area will again be open to shipping. The overall construction period will be 15 years. Total costs are estimated at DM 11 billion, half for construction and one third for the resettlement programme. It is hoped that these costs will be recouped through the sale of electricity within 21 years.

\subsection{Nuclear power stations}

As far as Germany is concerned, the future for nuclear technology appears rather bleak. Since 1989 no new reactor has been connected to the grid, and German industry has not received a single order to build a commercial nuclear reactor since 1982 . However, the situation in the rest of the world is rather different: 60 nuclear power stations have gone into operation since the Chernobyl disaster in 1986, and currently 48 new plants are under construction. It is quite clear that the world is not about to do away with nuclear power. Whether it is right for Germany to stand by and not actively accompany this development is an extremely important question which will have significant consequences extending far into the next century.

In any case the insurance industry is closely observing the global construction and operation of nuclear power stations. With their sums insured of up to DM 5 billion per 1,300 MW unit these plants constitute large-scale risks indeed. 
The operation of nuclear power stations, including both conventional and nuclear risks, is insured by the global network of national Nuclear Pools, which have a system of reinsuring one another. There are of course limits of indemnity determined by the capacities available to the Pools. For each property loss event involving a nuclear power station there is a world market capacity of approximately DM 2.5 billion available. In liability insurance the cover usually corresponds to the operator's compulsory cover prescribed by national legislation and is significantly lower.

Such restrictions do not exist for the construction risk and the machinery breakdown risk during operation. These risks can be insured at full value outside the Nuclear Pools in the conventional insurance markets, and the Munich $\mathrm{Re}$ has been heavily involved worldwide since the peaceful use of nuclear energy began, including technologically highly advanced projects such as the Japanese fast breeder reactor Monju. For a long time Monju was the Munich Re's biggest engineering risk. How complicated the project is can be seen from the duration of the until recently very successful construction and commissioning phases, which will amount to ten years by the time of the previously scheduled commencement of commercial operation in September 1996. However, a sodium leak, which occurred in December 1995 as a result of the fracture of a temperature sensor sheath, will delay this starting date, even if the damage was of only minor importance from a safety point of view. This is an example of the long-term nature of major engineering risks.

\subsubsection{Eastern Europe}

An exception in the insurance of nuclear power stations have been the plants of Russian design in Eastern Europe, which were all owned by the state and therefore not insured. Increasing privatisation combined with orders Western companies have received to retrofit these plants, have started to create a demand for insurance of these power stations.

The insurers are fully aware that they have to carry out very thorough inspections of each one of these plants with regard to the safety standards applied on site and the safety awareness of the operator. For several years now insurers have been cooperating on an international basis to make the necessary preparations, involving close contact with specialist technical organisations and inspections for the purpose of studying the particular features of these widely varying types of plant.

The insurance of the first of these plants was agreed in autumn 1995, albeit only for the construction phase, i.e. for non-nuclear perils. The risk concerned are the two 1,000 MW units of the Temelin plant in the Czech Republic, built to the latest design of Russian nuclear power station. The main weak point in this design is the outdated technology in the control, instrumentation and safety systems. A DM 350 million order has been placed to replace these systems with the latest Western technology.

The first enquiry for operating cover of an Eastern European plant of Russian design has been made to the Nuclear Pools for the Hungarian Paks plant, which has an excellent operational record in terms of worldwide comparison. Units of the same type have been in operation and insured in Finland for over 15 years. 


\subsection{Solar energy}

In addition to hydro-electric power, the most important of the renewable energies will be the thermal use of solar energy for the production of hot water and electricity as well as the large-scale application of photovoltaic conversion of the sun's energy into electrical current by means of solar cells. The economic breakthrough for these technologies is still being prevented by the fact that environmental damage, the so-called «external costs» that conventional technologies entail, is not being included in the price of electricity generated by the various types of plant.

In regions of the world that enjoy high sunshine intensity and duration, both the above-mentioned methods of using solar energy are today feasible in terms of technology, overall energy payback and environmental soundness. They will make an increasingly important contribution to relieving the problems of energy supply, carbon dioxide emission and thus climate change, initially in the form of smaller installations and later in the form of large-scale plants.

\subsection{Hydrogen technology}

Following on from this, a technology exists that has the potential to extend far into the third millennium and bring a host of changes to our daily lives: the introduction of hydrogen-based energy transport and distribution systems to distant consumers of energy obtained from solar, hydro-electric and nuclear plants. It is also important that by using hydrogen for energy storage the problem of the intermittent solar energy can be solved. The importance of this technology is its capability to provide a constant supply of energy to consumers long distances from the generating plants themselves, which would be remote hydro-electric power stations, nuclear power stations in sparsely populated areas and major industrial photovoltaic plants in sunny countries with large areas of land available. Countries with great reserves of hydro-electric power and solar energy, especially threshold and developing countries, should be interested in becoming future exporters of energy to the industrial centres in temperate climate zones.

The Euro-Québec Pilot Project [11] has been designed as a prototype for such systems, even if financing will not be possible in the short term. In Canada, direct current obtained from hydro-electric power stations would split water into hydrogen and oxygen by means of electrolysis and the hydrogen would be transported to Europe to be used as fuel. Hydrogen can be stored in tanks or caverns and transported as a gas in pipelines, in liquid form at very low temperature or as a chemical compound in tankers, rail tankers or tanker lorries. It is technically possible for all combustion processes in heating and hot water systems, in engines for vehicles and ships, in stationary gas turbines and even in aircraft engines to use hydrogen, which burns to water instead of $\mathrm{CO}_{2}$. This will produce only $1 \%$ of the nitrogen oxide released in burning oil. In fuel-cell plants electricity can be produced combined with heating steam, also free of pollutants.

How this can be achieved on a large scale was described ten years ago by Reinhard Dahlberg[12] and later advocated by others, above all by Ludwig Bölkow. Dahlberg's «Solar Hydrogen Project» envisages constructing 100 solar plants in the space of 20 years with a net solar cell area of $20 \mathrm{~km}^{2}$ each. North Africa would easily have enough space for the required area of $5,000 \mathrm{~km}^{2}$. However, these plants would only cover $0.2 \%$ of the 
world's energy requirements in the form of hydrogen. The nuclear power stations in Germany today alone could produce three times as much hydrogen.

The entire project, including the electrolysis plants and pipelines, would require an investment of some DM 400 billion and take 4 million man-years to complete. Dahlberg sees one of the main benefits of the project in reducing mass unemployment in industrialised countries and helping to alleviate its great social effects on communities. He carried out calculations for the project as a state-financed employment programme and came to the result that $80 \%$ of the project would be paid for within 25 years due to its self-financing nature (savings on unemployment benefits, revenue from income tax, etc.)

Even if that may be a somewhat optimistic statement, and the realization of the programme is not in sight, this project would indeed be ideal for establishing major technologies in threshold countries. It would lead to the setting up of manufacturing industries, technical infrastructure and inevitably also to local insurance industries. Obviously, such enormous projects would require a long-term insurance concept between local and international insurers and reinsurers.

\section{Structural engineering}

Structural engineering presents great challenges to the insurance industry in terms of the concentration of values in each risk, required insurance capacity, exposure of the risk and underwriting know-how. Construction sites are particularly exposed to natural hazards, and the exposure to windstorm or flooding is especially high. The case of the Schürmann building in Bonn is a good example, which was, however, not insured. In August 1994 in Taiwan the building site of a stainless steel factory on the outskirts of Kaoshiung was flooded following a typhoon. This event became the Munich Re's biggest ever loss in engineering insurance. The claim was finally settled at DM 140 million, with the Munich Re's share at about $40 \%$.

The adjustment of such losses is not left to insurers alone. If need be, the reinsurer's engineers will jointly with the insurer negotiate on site, in order to identify any unjustified claims and to limit indemnification to a fair amount.

\subsection{Road and rail technology}

\subsubsection{Trans-Tokyo-Bay Highway}

An impressive Japanese construction project is the highway under and over Tokyo Bay. Construction was started in 1987 and is due to be completed in 1997. On the Kawasaki side, where there is heavy shipping, the highway is to be built in the form of two parallel $10 \mathrm{~km}$ tunnels, each with a diameter of $14 \mathrm{~m}$. Halfway along the tunnels an artificial island is being constructed to serve as a ventilation shaft. It is situated at a water depth of $28 \mathrm{~m}$ and has foundations $70 \mathrm{~m}$ deep. On the other side, the highway runs along a $5 \mathrm{~km}$ long bridge. The crossover from the bridge to the tunnels also requires the construction of an artificial island. At a point where the water is $30 \mathrm{~m}$ deep the tunnel is sunk into soft ground at a depth of $40-50 \mathrm{~m}$ under the surface of the water. The total costs for the project are estimated at DM 9 billion. 


\begin{tabular}{|c|c|c|}
\hline 2050 & $\begin{array}{l}\text { - Offshore high-rise cities for up to } \\
500,000 \text { inhabitants, over } 1,000 \mathrm{~m} \\
\text { high } \\
\text { - Settlement of peripheral areas of } \\
\text { steppes and deserts with large-scale } \\
\text { irrigation projects } \\
\text { - Worldwide scrapping of old nuclear } \\
\text { power stations }\end{array}$ & $\begin{array}{l}\text { - Tokyo-Osaka link by Geoplane, i.e. airplane } \\
\text { in tunnel } \\
\text { - Tunnel/bridge link between Europe and } \\
\text { Africa via Sicily or Gibraltar } \\
\text { - Worldwide project to renovate water dams } \\
\text { Design lifetime: } 100 \text { years }\end{array}$ \\
\hline 2010 & $\begin{array}{l}\text { - Tokyo Millennium Tower: } \\
50,000 \text { inhabitants, } 850 \mathrm{~m} \text { high } \\
\text { - High-speed rail network in Europe }\end{array}$ & $\begin{array}{l}\text { - Large-scale reclamation of coastal land } \\
\text { - Extensive coastal protection against } \\
\text { flooding } \\
\text { - Brenner base tunnel }\end{array}$ \\
\hline 2000 & $\begin{array}{l}\text { - Petronas Towers, Kuala Lumpur } \\
\text { - Tuntex Tower, Taiwan } \\
\text { - Hong Kong Airport }\end{array}$ & $\begin{array}{l}\text { - Osaka Bay artificial islands } \\
\text { - Trans-Tokyo-Bay Highway } \\
\text { - Öresund Traverse }\end{array}$ \\
\hline 1995 & $\begin{array}{l}\text { - Kansai Airport } \\
\text { - New Munich Airport }\end{array}$ & $\begin{array}{l}\text { - Great Belt Link } \\
\text { - Channel Tunnel } \\
\text { - Great Man Made River, Libya }\end{array}$ \\
\hline
\end{tabular}

\section{Synopsis of major construction projects}

Inevitably, there have been a number of losses, including two major losses as a result of incorrect placing of the up to $100 \mathrm{~m}$ deep bored pile walls, within which the artificial islands were laid. Explosive inflows of water flooded the deep excavation pits. In both cases it took several weeks to complete the job of sealing and pumping. Together the loss amounts came to approximately DM 25 million. These sums could only be agreed after lengthy negotiations on site by expert engineers from Munich and Tokyo, who supported the Japanese insurers.

\subsubsection{Channel Tunnel}

Another interesting construction project nearer to home was the tunnel under the English Channel. What was once a construction risk has now become an operating risk. The construction phase lasted 7 years and was insured under a single CAR policy, which covered the entire period. As with the Trans-Tokyo-Bay project, this is an example of the long-term nature of the liability that insurers and reinsurers have to assume for CAR and EAR insurance of major projects.

Fortunately, and in spite of over 900 individual losses, no major losses occurred during the construction of the Channel Tunnel. The reinsurer was therefore able to make a profit on this project, which is needed to pay claims elsewhere. Probably the most important purpose of reinsurance is to balance a range of similar risks in terms of both geographical and temporal distribution. During the construction period the Munich Re maintained close contacts with the manufacturer and operator of the Channel Tunnel. In cooperation with the leading insurers in France and England, the Munich Re carried out negotiations for the operating cover and was again the leading reinsurer. Effective since April 1994, this cover encompasses the property insurance for all Eurotunnel's assets amounting 
to approximately DM 7 billion, including all its rolling stock, and the insurance of approximately DM 700 million for business interruption resulting from insured loss events. So far, these covers have largely been free of losses. The greatest potential hazards for the tunnel are a collision of two trains in the tunnel, a fire in the tunnel during the shipment of flammable goods or a fire in one of the computerised control centres in France or England, which would bring traffic to a standstill for a considerable length of time.

\subsubsection{Great Belt Link}

Building contractors, insurers and reinsurers of this project, which links the two large Danish islands Funen and Seeland, have not been quite so lucky as those involved in the Channel Tunnel. This $17.5 \mathrm{~km}$ long road and rail link contains two bridge sections of $6.6 \mathrm{~km}$ and $6.8 \mathrm{~km}$, including the longest suspension bridge in the world with a span of $1,624 \mathrm{~m}$. It also incorporates a dual tunnel $8 \mathrm{~km}$ long. The sum insured is approximately DM 4 billion. An insurance cover placed in the London market encompasses the entire construction risk for the bridges and tunnels, the enlargement of the island Sprögo, the technology for the railway, electricity and signals, and the access roads.

The first setback for the building contractors came in October 1991 when a water inflow completely flooded one of the tunnel boring machines, the entire length of the then only $200 \mathrm{~m}$ long tunnel, the excavation pit on Sprögo and the second machine in the other tunnel from the unprotected rear side. The result was a delay of more than a year and paid material losses of almost DM 45 million. A second major loss occurred when oil from a burst hydraulic tube caused a fire in one of the tunnel boring machines. Although the machine only had some $300 \mathrm{~m}$ to go, it had to be written off as a total loss. The concrete casing of the tunnel was also seriously damaged but was not destroyed. The costs amounted to approximately DM 20 million and the delay to 9 months.

\subsection{Airports}

The number of air passengers is increasing throughout the world. Some major airports expect increases of up to $80 \%$ by the year 2000 . As many airports cannot expand further, new major airports are on the drawing board, under construction or have recently been put into operation, for example the Kansai International Airport at Osaka with the largest ever man-made island of $12 \mathrm{~km}^{2}$. Several insurance policies for this major construction site amounted to a total sum insured of over DM 3.2 billion for terminals, access bridges ( $3.7 \mathrm{~km}$ long) and surrounding dams and dykes. The airport has been in operation since 1994.

New dimensions are being created by the new Hong Kong airport and its link to the city centre. Two islands some $35 \mathrm{~km}$ from the centre of Hong Kong were levelled and an area of some $12.5 \mathrm{~km}^{2}$ was created with additional material. The costs for this project amounted to over DM 8 billion. The link to the airport itself constitutes a major infrastructure project. Major excavation work was necessary to create the substructure for the motorway and two rail links. Also under construction are a large cable-stayed bridge and a suspension bridge, whose span of $1,377 \mathrm{~m}$ will make it the second longest in the world. The costs for this part of the project amount to another DM 7.5 billion. The situation is compounded by the severe time pressure under which work has to be carried out. The comple- 
tion date has been set for 30.6.1997, the day Hong Kong will be handed over to the People's Republic of China.

But this is not the only major airport project under construction:

- On 1.1.1998 the first plane is due to take off from Sepang near Kuala Lumpur. More than 100 million $\mathrm{m}^{3}$ of earth had to be excavated to create space for 2 runways, terminals and hangars. The total costs of this project are DM 3.9 billion.

- After many years' delay, Athens' new major airport at Spata, some $25 \mathrm{~km}$ from the city centre, is finally taking shape.[2] A consortium of companies has received the contract for this DM 3.2 billion project and will operate the airport for a period of 25 years on the basis of the BOT model (cf Section 2.1).

\subsection{High-rise buildings}

The growth of cities has led to a massive increase in their areas, with resultant traffic problems and great amounts of time lost by commuters. The Japanese government is investigating a $1,000 \mathrm{~m}$ high tower, which is to form a complete town under one roof with offices, schools, apartments, a theatre, a hospital, and a host of other facilities. Studies subsidised by the state are due to be concluded in 1999 and many reputable firms are taking part. Critics say that the problems of traffic congestion are simply being shifted from the streets to the lifts. The technical problems involved are enormous: water supplies, garbage disposal, not to mention the building materials themselves. Apart from this, the social effects of such gigantism have not been researched either.

A somewhat more modest project, which is already well under way, are the two towers of the Kuala Lumpur City Centre, the Petronas Towers. These are due for completion in 1996 and with a height of $492 \mathrm{~m}$, which has already been reached, have eclipsed the Sears Tower in Chicago as the tallest building in the world. The Sky Bridge, which connects the towers at a height of $190 \mathrm{~m}$, was lifted into position hydraulically in August 1995. The construction of the Petronas Towers is insured for a sum of DM 1.65 billion. However, Kuala Lumpur will not hold the record for long. In Shanghai's new financial and business district, Pudong, Japanese constructors are erecting a building that will be $8 \mathrm{~m}$ taller than the Petronas Towers.

In Taiwan, the Munich $\mathrm{Re}$ is the leading reinsurer of a building with a height of some $300 \mathrm{~m}$, the Tuntex Tower, which boasts one particularly remarkable feature. In order to minimise swaying of the building during earthquakes or typhoons, a type of reverse pendulum is to be incorporated, whose weight, placed on one of the upper storeys, is moved by electronic remote control in such a way that the swaying of the building as a result of wind force or earthquake is reduced significantly.

\section{Requirements for insurers and reinsurers}

These examples of energy and construction technologies are intended to show how varied and technically demanding major engineering risks are for insurers.

They are also exposed to a great range of perils, with natural hazards such as windstorm, earthquake and flooding being the most important and dangerous. The perils of 
fire, explosion and lightning are also of significance and the third great hazard consists in venturing into new technological terrain: Technology is innovative, it opens up new dimensions and opportunities, but at the same time it presents new risks.

In order to be able to accept these risks in a commercially responsible way, insurers and reinsurers must be able to carry out their own risk assessment. This must be done both retrospectively and prospectively. This means using the knowledge of similar past risks and evaluating worldwide claims experience. In addition, future developments in technology have to be considered and conclusions drawn for the purpose of risk development. Moreover, a skilled insurer will also carry out on-site analyses of safety standards at a major technical risk during erection and operation. On this basis he will be able to assess the risk as accurately as possible with regard to the probability and extent of losses and establish his own position regarding insurance conditions, premiums and deductibles.

\section{REFERENCES}

Mittelstraß, J., Angst ist etwas völlig Normales - In: VDI-Nachrichten No. 32, 9.8.1991, p 25.

Hochtief AG, Essen.

Nierhaus, F., Die Rückversicherungsmärkte heute - kurz- und längerfristige Herausforderungen und Chancen, ZfV 44, No. 21 (1993).

Energy Systems Today and Tomorrow, Munich Reinsurance Company (1990).

World Energy Council, Energy for Tomorrow's World, New York (1993)

RWE, Chancen und Risiken der künftigen Weltenergieversorgung, Essen, May 1994.

2100 - récit du prochain siècle, Editions Payot, Paris (1990).

Financial Times of 16.5.1995 from GEC Alsthom.

BP Statistical Review of World Energy, June 1995.

Reserven, Ressourcen und Verfügbarkeit von Energierohstoffen 1995, Bundesministerium für Wirtschaft, Bonn, Sept. 1995.

Sulzer Hydro, Zürich.

Ludwig-Bölkow-Systemtechnik GmbH, Ottobrunn.

R. Dahlberg, Solarer Wasserstoff - Großtechnologie für Wirtschaftswachstum und Beschäftigung, (1985) R. Dahlberg in: H. Scheer (Hrsg.), Die gespeicherte Sonne, Serie Piper 828 (1987).

Parts of this article are based on H. Huppmann, ZVersWiss, No. 1/2 (1992),

H. Huppmann, G. Duesing, ZfV $\underline{46}$ (1995) 557, and VW $\underline{50}$, No. 21/22/23 (1995) 